\title{
11. THE OBLIQUE SEISMIC EXPERIMENT ON DEEP SEA DRILLING PROJECT LEG 70 ${ }^{1}$
}

\author{
R. A. Stephen, Woods Hole Oceanographic Institution, Woods Hole, Massachusetts
}

\begin{abstract}
A bore-hole seismic experiment was carried out in Deep Sea Drilling Project Hole 504B, in the Costa Rica Rift area of the east Pacific. In this experiment the clamped bore-hole geophone was deployed deeper into oceanic crust ( $542 \mathrm{~m}$ ) than in any previous seismic experiment. Comparison of travel-time data for the geophone at two depths in the hole and an ocean-bottom hydrophone demonstrates clearly the advantages of bore-hole receivers in interpreting shallow crustal structure in the presence of a sediment layer (in this case, $275-\mathrm{m}$ thick). The lowest velocity directly detected by the ocean-bottom receivers was $5.11 \pm 0.18 \mathrm{~km} / \mathrm{s}$, compared to $4.59 \pm 0.09 \mathrm{~km} / \mathrm{s}$ for the geophone clamped at 52 meters into basement. A velocity model of the upper crustal structure consistent with the travel-time data at all three levels was constructed. The scatter in observed Layer 2 velocities can be explained by sampling different parts of the same velocity-depth structure and does not require lateral inhomogeneity. As in previous oblique seismic experiments, no evidence for anisotropy was found from travel-time analysis.
\end{abstract}

\section{INTRODUCTION}

The objective of the bore-hole seismic experiment was to determine the small-scale velocity structure of the crust penetrated by the drill hole $(<10-\mathrm{km}$ radius). Anisotropy, attenuation, and lateral inhomogeneity were considered as aspects of the velocity structure. A description of previous oblique seismic experiments (OSE) can be found in Stephen (1979), Stephen, Louden, and Matthews $(1979,1980)$, and Stephen, Johnson, and Lewis (in press).

In the Leg 70 OSE, only travel time-data were acquired in the bore-hole and particle-motion analysis of anisotropy (Stephen, 1981), and attenuation measurements could not be made. Amplitude information on ocean-bottom hydrophones (OBHs), which were also deployed in the area, was inconsistent between lines, and no amplitude analysis was carried out. The travel-time data were interpreted by the slope-intercept method, and no anisotropy was observed.

\section{THE EXPERIMENT}

The Leg 70 OSE was carried out in Hole 504B, in the Costa Rica Rift area. The significant depths in the hole are shown in Table 1. Three ocean-bottom hydrophones (Koelsch and Purdy, 1979) were also deployed, as shown in Figure 1. The shot locations for the geophone at $\mathbf{5 2}$ and 542 meters into basement with $\mathrm{OBHs}$ and for the $\mathrm{OBHs}$ alone are also shown. Shot sizes ranged from 7 to $27 \mathrm{~kg}$. The shooting ship was the R/V Gillis.

\section{DATA REDUCTION AND INTERPRETATION}

Because the reflection-profiling data are too sparse to permit compilation of a sediment-thickness map, the travel times were corrected for topography, assuming that basement contours follow bathymetry (Fig. 2). (The

1 Cann, J. R., Langseth, M. G., Honnorez, J., Von Herzen, R. P., White, S. M., et al., Init. Repts. DSDP, 69: Washington (U.S. Govt. Printing Office).
Table 1. Significant depths in Hole 504B.

\begin{tabular}{lccc}
\hline & $\begin{array}{c}\text { Depth from } \\
\text { Rig Floor } \\
(\mathrm{m})\end{array}$ & $\begin{array}{c}\text { Depth from } \\
\text { Mudline } \\
(\mathrm{m})\end{array}$ & $\begin{array}{c}\text { Depth into } \\
\text { Basement } \\
(\mathrm{m})\end{array}$ \\
\hline $\begin{array}{l}\text { Sea level } \\
\text { Mudline }\end{array}$ & 10 & & \\
$\begin{array}{l}\text { Basement } \\
\text { Shallow geophone } \\
\text { position }\end{array}$ & 3473 & 275 & \\
$\begin{array}{l}\text { Deep geophone } \\
\text { position }\end{array}$ & 3800 & 327 & 52 \\
\hline
\end{tabular}

sediment thickness at the bore-hole is $\mathbf{2 7 5}$ meters.) The travel-time plots and topography are shown in Figure 3, and the results of the slope-intercept analysis are given in Table 2.

The lowest measured velocities (Layer 2B) for the deep and shallow geophone positions and OBHs were significantly different, and the corresponding energy was interpreted to have come from different depths. This will be discussed further below; however, it is important to note that even for the same receiver geometry there is wide scatter in the Layer 2B velocities, which suggests variations due to lateral inhomogeneity or sampling and experimental error. The scatter cannot be explained by azimuthal anisotropy or by dipping refractors. In contrast, the velocities for Layer $2 \mathrm{C}$ were consistent for all receivers, and Layer $2 \mathrm{C}$ seems to be a continuous refractor in the area. Except for the northeast line shot to $\mathrm{OBH} 8$, all the $\mathrm{OBH}$ values are consistent with a 6.44 $\mathrm{km} / \mathrm{s}$, flat, laterally homogeneous, and isotropic refractor.

The velocity-depth structure in basement was determined by trial-and-error forward modeling of the traveltime data for each receiver, averaged over all azimuths. A rigorous $\tau-\mathrm{p}$ inversion (Bessonova et al., 1974; Garmany et al., 1979; Orcutt, 1980; Dorman and Jacobson, 1981) was not carried out, because these methods require an estimate of the uppermost velocity. The pur- 

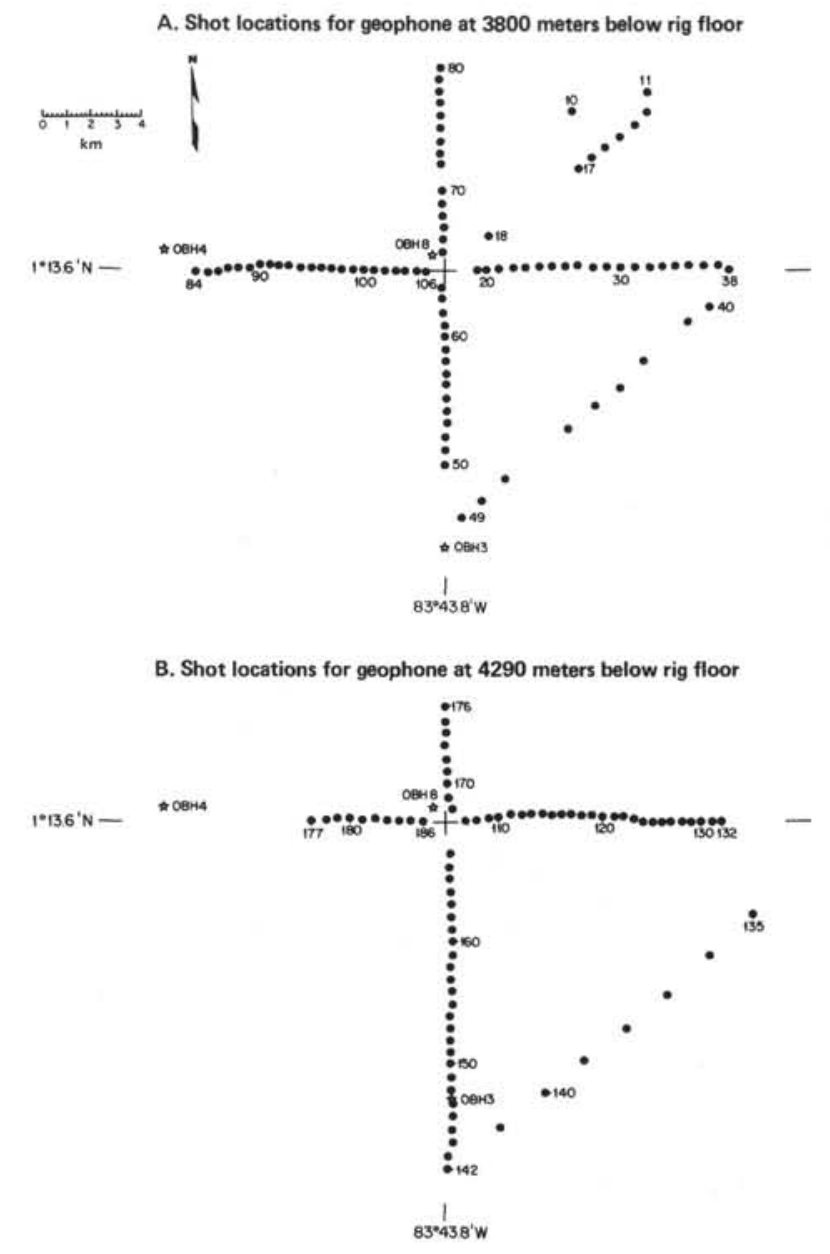

c. Shot locations for OBHs only

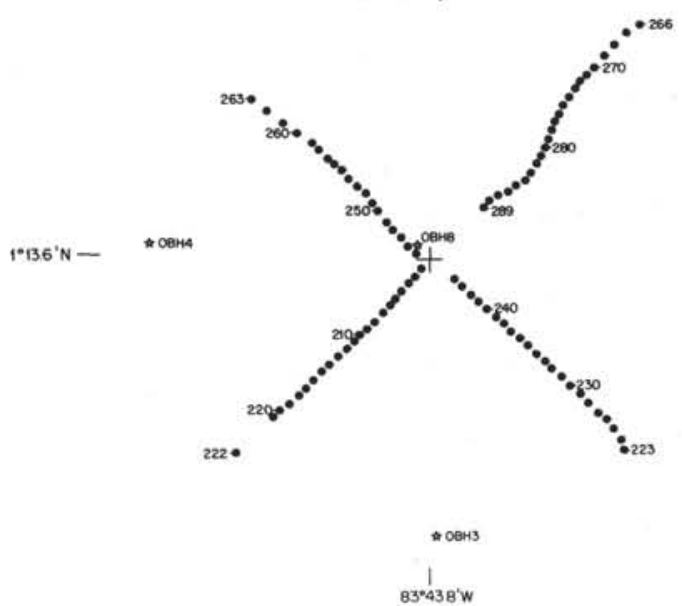

Figure 1. Shot locations relative to the borehole (crossed lines) for the shallow geophone position and OBHs (A), for the deep geophone position and $\mathrm{OBHs}(\mathrm{B})$, and for the OBHs by themselves (C). The spreading direction in the area is north-south.

pose of this work was to determine the shallow velocity structure, so, rather than assuming an uppermost velocity, it was assumed that the velocity structure consisted of constant-gradient segments (Fig. 4). (Amplitude analysis of other data sets has shown that oceanic crustal structure is modeled better by constant-gradient seg- ments than by constant-velocity layers [Helmberger and Morris, 1969, 1970; Orcutt et al., 1976; Stephen et al., 1979].) The travel-time analysis carried out here is, in a sense, intermediate between the traditional approach (i.e., determining the velocity and thickness of constantvelocity layers from straight-line segments through the observed data) and the modern approach (i.e., $\tau-p$ inversion of the time-distance pairs).

We have identified two distinct line segments on the travel-time curve, corresponding to seismic Layers 2B and $2 \mathrm{C}$ in oceanic crust (Houtz and Ewing, 1976). The problem is to determine the gradients and uppermost velocities in each layer which generated the observations. This was accomplished by calculating the timedistance curve for a postulated velocity-depth structure, reducing this synthetic data set to slope-intercept values in the same manner as the observations, and then comparing the synthetic and observed values. The procedure was repeated, modifying the postulated structure, until agreement was obtained between synthetic and observed values for all receivers. In determining the slope-intercept values for the synthetic curves, it was assumed that data points were present every $0.1 \mathrm{~km}$, and the same range windows were used as for the observed data. The Layer $2 \mathrm{C}$ analysis was carried out assuming the "best" solution for the Layer 2B structure.

Figure 5 shows the velocity-depth models used, and Tables 3 and 4 compare the model and observed values. Note that the confidence limits $(67 \%)$ for the model values are the standard limits from the linear-regression analysis of the computed curves, which are not straight lines (e.g., Fig. 6). These limits are computed in the same manner for both the observed and synthetic data sets. They are larger for the observed data because the observed points have scatter due to the experimental errors (Stephen et al., 1979). The estimated error for relative times is $\pm 0.025 \mathrm{~s}$, not including the effect of unknown basement topography; the estimated error for ranges is \pm 24 meters. The limits for OBH 8 are larger than for the other receivers (allowing for the number of data points) because of a problem in the tape recording process which introduced more uncertainty into the travel times.

It was possible to explain the observed Layer $2 \mathrm{~B}$ velocities on the bore-hole receivers and OBH 8 by a single gradient. The best solution from this method was a gradient of $1.5 \mathrm{~s} \mathrm{~s}^{-1}$ from a surface velocity of $4.4 \mathrm{~km} / \mathrm{s}$ to a depth of $1 \mathrm{~km}$ into basement. It was necessary to invoke two gradients to explain the observed Layer $2 \mathrm{C}$ arrivals: a gradient of $0.73 \mathrm{~s}^{-1}$ for another $1.2 \mathrm{~km}$ (Layer 2C), and below this a gradient of $0.02 \mathrm{~s}^{-1}$ (Layer 3). This structure is consistent with all observations except the Layer $2 \mathrm{~B}$ velocities and intercepts on OBHs 3 and 4 and the Layer $2 \mathrm{C}$ intercepts for OBHs 3 and 4 . These values will be sensitive to unknown sediment thickness at large ranges from the hole. Travel-time curves for the "best fit" structure are compared with the data in Figure 6.

\section{DISCUSSION}

The structure near Site 504 contrasts sharply with the observed structure in the ROSE (Rivera Ocean Seismic Experiment) area (Ewing and Purdy, in press) which is 


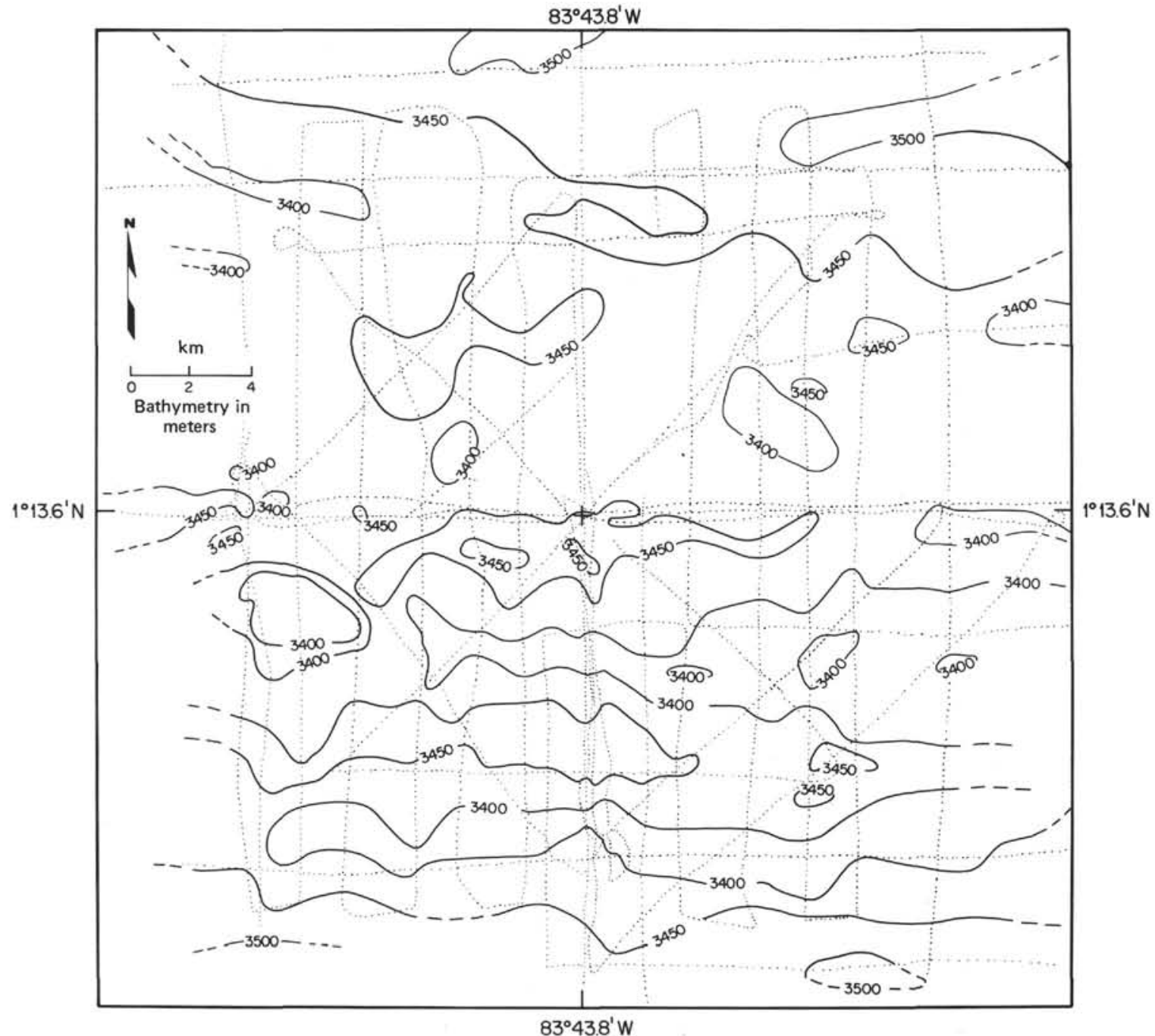

Figure 2. Bathymetry in corrected meters in the immediate vicinity of DSDP Hole 504B.

about the same age ( $\leq 6$ m.y.). In the ROSE area, the shallowest gradient is about $3.0 \mathrm{~s}^{-1}$, with an upperbasement velocity of $2.8 \mathrm{~km} / \mathrm{s}$. It is tempting to speculate that the high-velocity crust is found under sediment ponds, and that where there is no sediment the uppercrust velocities are very low. Assuming that the crust in the east Pacific formed with the same initial crack distribution, it appears that a sediment layer above the crust encourages consolidation of cracks.

\section{ACKNOWLEDGMENTS}

I would like to thank Captain Clarke, the officers and crew of the Glomar Challenger, the drilling personnel, the DSDP marine engineers and technicians, Captain Hagen, the officers and crew of the Gilliss, Mr. E. Young, Mr. J. Broda, Mr. C. Grant, Mr. S. Gegg, Ms. K. Rohr, and Dr. R. P. Von Herzen for their assistance in running the experiment, and Ms. N. Lian, Ms. D. Allison, and Mr. L. Gove for their assistance in reducing the data. Drs. R. P. Von Herzen and G. M. Purdy reviewed the manuscript and made helpful suggestions. This work was supported by the National Science Foundation under Contract OCE79-09351. The Woods Hole Oceanographic Institution Contribution Number is 4739 .

\section{REFERENCES}

Bessonova, E. N., Fishman, V. M., Ryaboyi, V. Z., and Sitnikova, G. A., 1974. The tau method for inversion of travel times. 1. Deep seismic sounding data. Geophys. J. Royal Astron. Soc., 36: 377-398.

Dorman, L. M., and Jacobson, R. S., 1981. Linear inversion of body wave travel time data. Geophysics, 46:138-151.

Ewing, J. I., and Purdy, G. M., in press. Upper crustal velocity structure in the ROSE area of the East Pacific Rise. J. Geophys. Res.

Garmany, J., Orcutt, J. A., and Parker, R. L., 1979. Travel time inversion: a geometrical approach. J. Geophys. Res., 84:3615-3622.

Helmberger, D. V., and Morris, G. B., 1969. A travel time and amplitude interpretation of a marine refraction profile: primary waves. J. Geophys. Res., 74:483-494.

, 1970. A travel time and amplitude interpretation of a marine refraction profile: transformed shear waves. Bull. Seismol. Soc. Am., 60:593-600.

Houtz, R. E., and Ewing, J. I., 1976. Upper crustal structure as a function of plate age. J. Geophys. Res., 81:2490-2498.

Koelsch, D. E., and Purdy, G. M. 1979. An ocean bottom hydrophone instrument for seismic refraction experiments in the deep ocean. Mar. Geophys. Res., 4:115-125. 


\section{R. A. STEPHEN}

Orcutt, J. A., 1980. Joint linear, extremal inversion of seismic kinematic data. J. Geophys. Res., 85:2649-2660.

Orcutt, J. A., Kennett, B. L. N., and Dorman, L. M., 1976. Structure of the East Pacific Rise from an ocean bottom seismometer survey. Geophys. J. Royal Astron. Soc., 45:305-320.

Stephen, R. A., 1979. The oblique seismic experiment in oceanic crust-equipment and technique. Mar. Geophys. Res., 4:213-226. 1981. Seismic anisotropy observed in upper oceanic crust. Geophys. Res. Lett., 8:865-868.

Stephen, R. A., Johnson, S., and Lewis, B., in press. The oblique seismic experiment on Deep Sea Drilling Project Leg 65. In Robin- son, P., Lewis, B., et al., Init. Repts. DSDP, 65: Washington (U.S. Govt. Printing Office).

Stephen, R. A., Louden, K. E., and Matthews, D. H. 1979. The oblique seismic experiment on Deep Sea Drilling Project Leg 52. In Donnelly, T., Francheteau, J., Bryan, W., Robinson, P., Flower, M., Salisbury, M., et al., Init. Repts. DSDP, 51, 52, 53, Pt. 1: Washington (U.S. Govt. Printing Office), 675-704.

1980. The oblique seismic experiment on DSDP Leg 52. Geophys. J. Royal Astron Soc., 60:289-300.
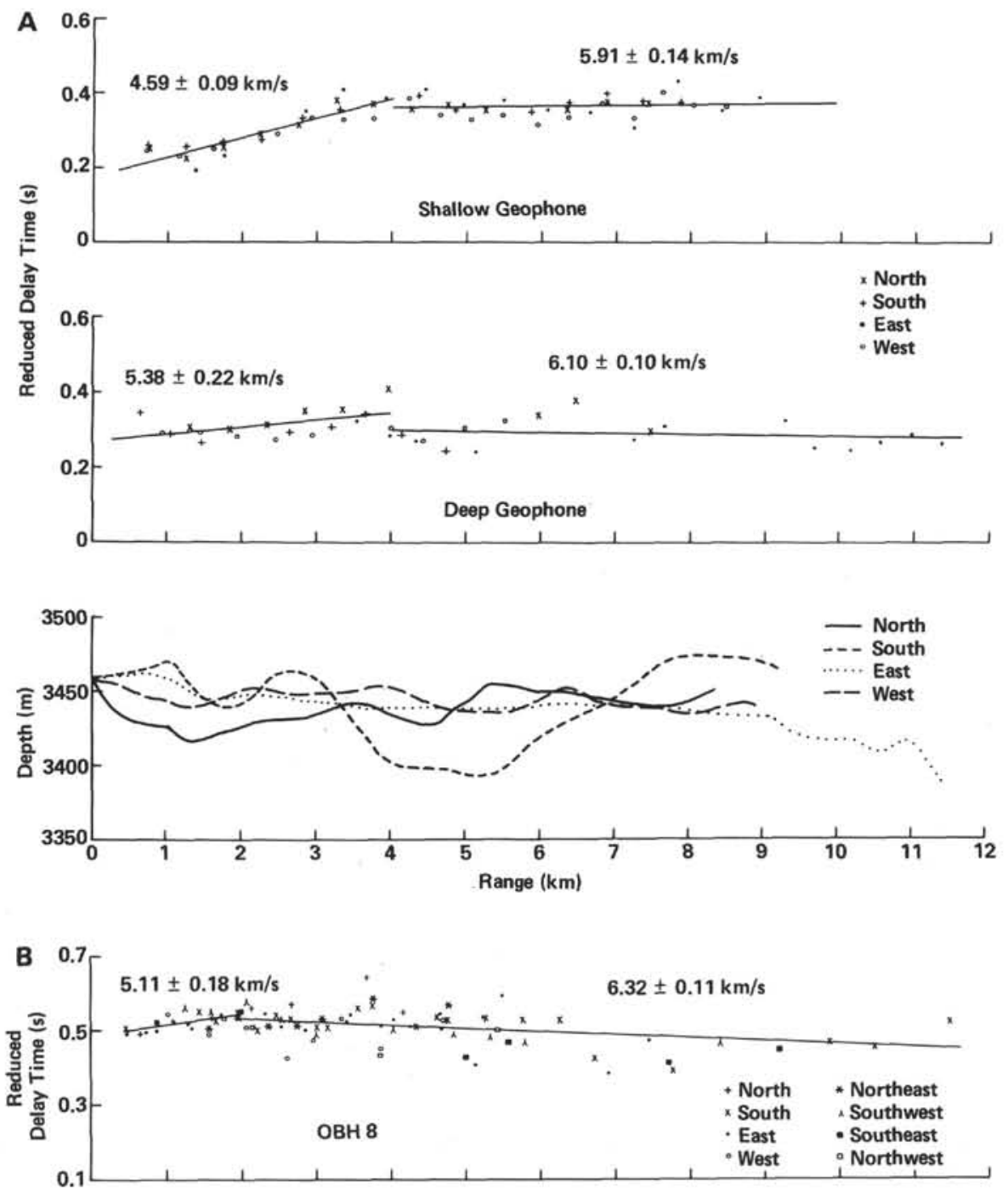

Figure 3. Reduced delay times and bathymetry plotted against range for the shallower and deep geophone positions (A), OBH \#8 (B), OBH \#3 (C), and OBH \#4 (D). The results of the leastsquares straight-line fits to the data with standard errors are also shown. The delay times were computed by assuming a refractor velocity of $5.0 \mathrm{~km} / \mathrm{s}$ for Layer $2 \mathrm{~B}$ and $6.0 \mathrm{~km} / \mathrm{s}$ for Layer $2 \mathrm{C}$. The reduction velocity is $6.0 \mathrm{~km} / \mathrm{s}$. 

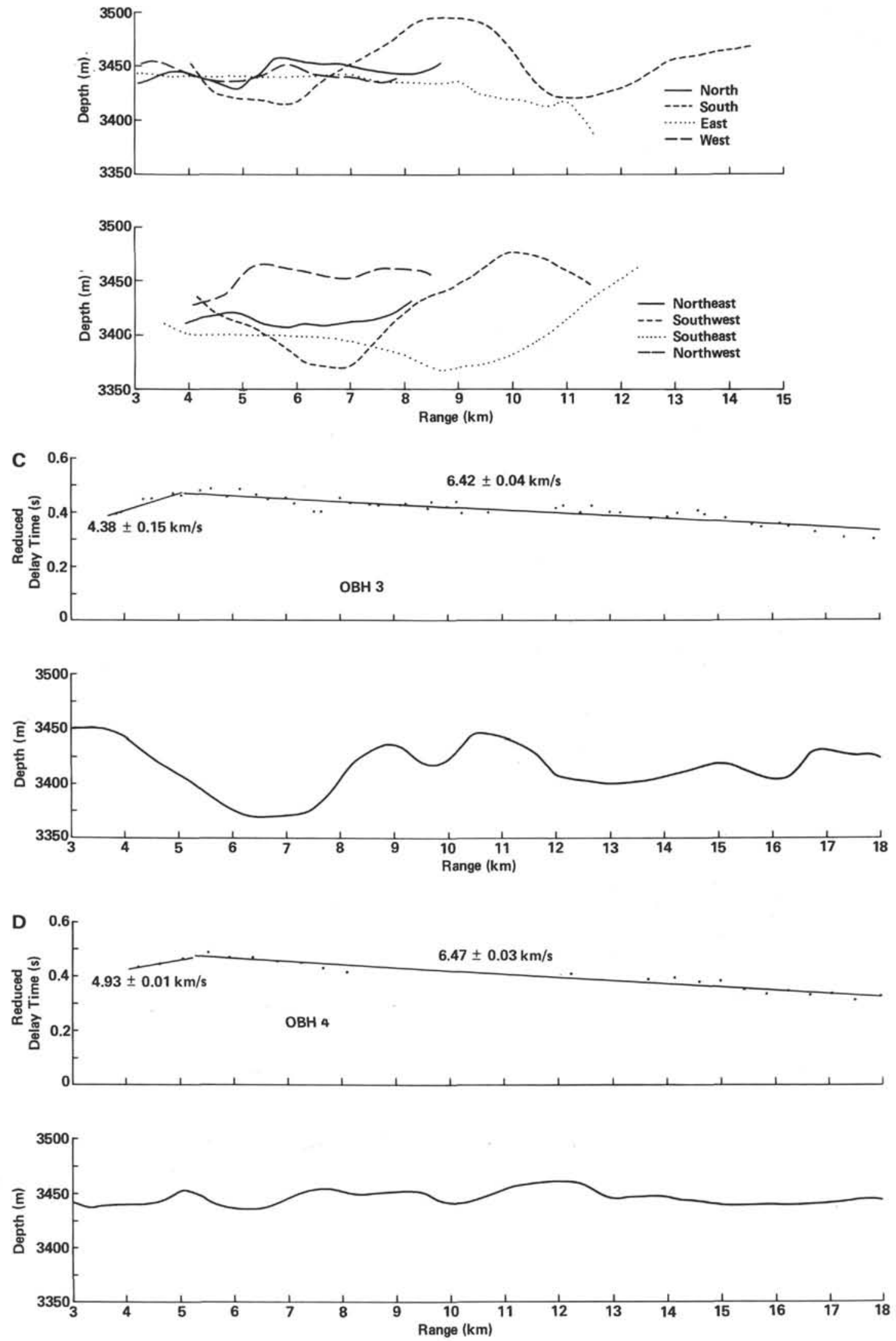

Figure 3. (Continued). 
Table 2. Slope-intercept analysis.

\begin{tabular}{|c|c|c|c|c|c|c|}
\hline & \multicolumn{3}{|c|}{ Layer 2B } & \multicolumn{3}{|c|}{ Layer $2 \mathrm{C}$} \\
\hline & $\begin{array}{l}\text { Intercept } \\
\text { Time } \\
\text { (s) }\end{array}$ & $\begin{array}{l}\text { Velocity } \\
(\mathrm{km} / \mathrm{s})\end{array}$ & $\begin{array}{c}\text { Number } \\
\text { of } \\
\text { Points }\end{array}$ & $\begin{array}{c}\text { Intercept } \\
\text { Time } \\
\text { (s) }\end{array}$ & $\begin{array}{l}\text { Velocity } \\
(\mathrm{km} / \mathrm{s})\end{array}$ & $\begin{array}{c}\text { Number } \\
\text { of } \\
\text { Points }\end{array}$ \\
\hline \multicolumn{7}{|l|}{ Shallow geophone } \\
\hline $\begin{array}{l}\text { North line } \\
\text { South line } \\
\text { East line } \\
\text { West line } \\
\text { North and south lines } \\
\text { East and west lines } \\
\text { All lines }\end{array}$ & $\begin{array}{l}0.207 \pm 0.020 \\
0.177 \pm 0.019 \\
0.090 \pm 0.018 \\
0.199 \pm 0.013 \\
0.190 \pm 0.010 \\
0.161 \pm 0.023 \\
0.178 \pm 0.011\end{array}$ & $\begin{array}{l}4.83 \pm 0.22 \\
4.55 \pm 0.16 \\
3.99 \pm 0.11 \\
4.88 \pm 0.12 \\
4.66 \pm 0.09 \\
4.50 \pm 0.17 \\
4.59 \pm 0.09\end{array}$ & $\begin{array}{r}6 \\
7 \\
6 \\
7 \\
7 \\
13 \\
13 \\
26\end{array}$ & $\begin{array}{l}0.365 \pm 0.062 \\
0.332 \pm 0.018 \\
0.376 \pm 0.022 \\
0.317 \pm 0.033 \\
0.345 \pm 0.023 \\
0.340 \pm 0.031 \\
0.347 \pm 0.026\end{array}$ & $\begin{array}{l}5.94 \pm 0.35 \\
5.81 \pm 0.10 \\
6.03 \pm 0.31 \\
5.83 \pm 0.17 \\
5.85 \pm 0.12 \\
5.90 \pm 0.16 \\
5.91 \pm 0.14\end{array}$ & $\begin{array}{r}7 \\
6 \\
9 \\
11 \\
13 \\
20 \\
33\end{array}$ \\
\hline \multicolumn{7}{|l|}{ Deep geophone } \\
\hline $\begin{array}{l}\text { North line } \\
\text { South line } \\
\text { East line } \\
\text { West line } \\
\text { North and south lines } \\
\text { East and west lines } \\
\text { All lines }\end{array}$ & $\begin{array}{r}0.248 \pm 0.023 \\
0.235 \pm 0.026 \\
- \\
0.291 \pm 0.003 \\
0.274 \pm 0.023 \\
0.268 \pm 0.018 \\
0.268 \pm 0.019\end{array}$ & $\begin{array}{c}5.83 \pm 0.32 \\
4.83 \pm 0.22 \\
- \\
6.15 \pm 0.06 \\
5.33 \pm 0.25 \\
5.66 \pm 0.24 \\
5.38 \pm 0.22\end{array}$ & $\begin{array}{r}6 \\
6 \\
- \\
5 \\
12 \\
6 \\
18\end{array}$ & $\begin{array}{c}- \\
0.567 \pm 0.265 \\
0.279 \pm 0.014 \\
0.220 \pm 0.104 \\
0.197 \pm 0.114 \\
0.302 \pm 0.018 \\
0.307 \pm 0.020\end{array}$ & $\begin{array}{c}- \\
7.56 \pm 2.27 \\
6.03 \pm 0.06 \\
5.44 \pm 0.64 \\
5.37 \pm 0.56 \\
6.11 \pm 0.09 \\
6.10 \pm 0.10\end{array}$ & $\begin{array}{r}2 \\
3 \\
11 \\
4 \\
5 \\
15 \\
20\end{array}$ \\
\hline \multicolumn{7}{|l|}{ ОВН 8} \\
\hline $\begin{array}{l}\text { North line } \\
\text { South line } \\
\text { East line } \\
\text { West line } \\
\text { Northeast line } \\
\text { Southwest line } \\
\text { Northwest line } \\
\text { Southeast line } \\
\text { North and south lines } \\
\text { East and west lines } \\
\text { Northeast and south- } \\
\text { west lines } \\
\text { Northwest and south- } \\
\text { east lines } \\
\text { All }\end{array}$ & $\begin{array}{c}0.381 \pm 0.118 \\
0.552 \pm 0.322 \\
0.386 \pm 0.021 \\
0.679 \pm 0.110 \\
- \\
0.469 \pm 0.193 \\
- \\
- \\
0.389 \pm 0.066 \\
0.470 \pm 0.067 \\
0.454 \pm 0.187 \\
0.435 \pm 0.073 \\
0.409 \pm 0.040\end{array}$ & $\begin{array}{c}4.93 \pm 0.66 \\
6.02 \pm 2.42 \\
5.02 \pm 0.07 \\
7.54 \pm 1.24 \\
- \\
5.31 \pm 1.12 \\
- \\
- \\
4.98 \pm 0.32 \\
5.59 \pm 0.41 \\
5.30 \pm 1.06 \\
5.23 \pm 0.38 \\
5.11 \pm 0.18\end{array}$ & $\begin{array}{r}4 \\
3 \\
7 \\
3 \\
2 \\
3 \\
1 \\
2 \\
7 \\
10 \\
\\
5 \\
\\
3 \\
25\end{array}$ & $\begin{array}{l}0.445 \pm 0.276 \\
0.581 \pm 0.045 \\
0.621 \pm 0.065 \\
0.300 \pm 3.92 \\
0.370 \pm 0.054 \\
0.566 \pm 0.039 \\
0.459 \pm 0.184 \\
0.463 \pm 0.128 \\
0.600 \pm 0.042 \\
0.570 \pm 0.066\end{array}$ & $\begin{array}{l}5.32 \pm 1.21 \\
6.28 \pm 0.16 \\
6.54 \pm 0.31 \\
5.10 \pm 1.61 \\
5.13 \pm 0.18 \\
6.33 \pm 0.14 \\
5.78 \pm 0.82 \\
6.05 \pm 0.43 \\
6.34 \pm 0.15 \\
6.31 \pm 0.30\end{array}$ & $\begin{array}{r}4 \\
18 \\
17 \\
4 \\
5 \\
7 \\
4 \\
4 \\
22 \\
21\end{array}$ \\
\hline \multicolumn{7}{|l|}{ OBH 3} \\
\hline North & $0.163 \pm 0.034$ & $4.38 \pm 0.15$ & 6 & $0.526 \pm 0.010$ & $6.42 \pm 0.04$ & 40 \\
\hline \multicolumn{7}{|l|}{ OBH 4} \\
\hline East & $0.283 \pm 0.001$ & $4.93 \pm 0.01$ & 3 & $0.541 \pm 0.010$ & $6.47 \pm 0.03$ & 19 \\
\hline
\end{tabular}




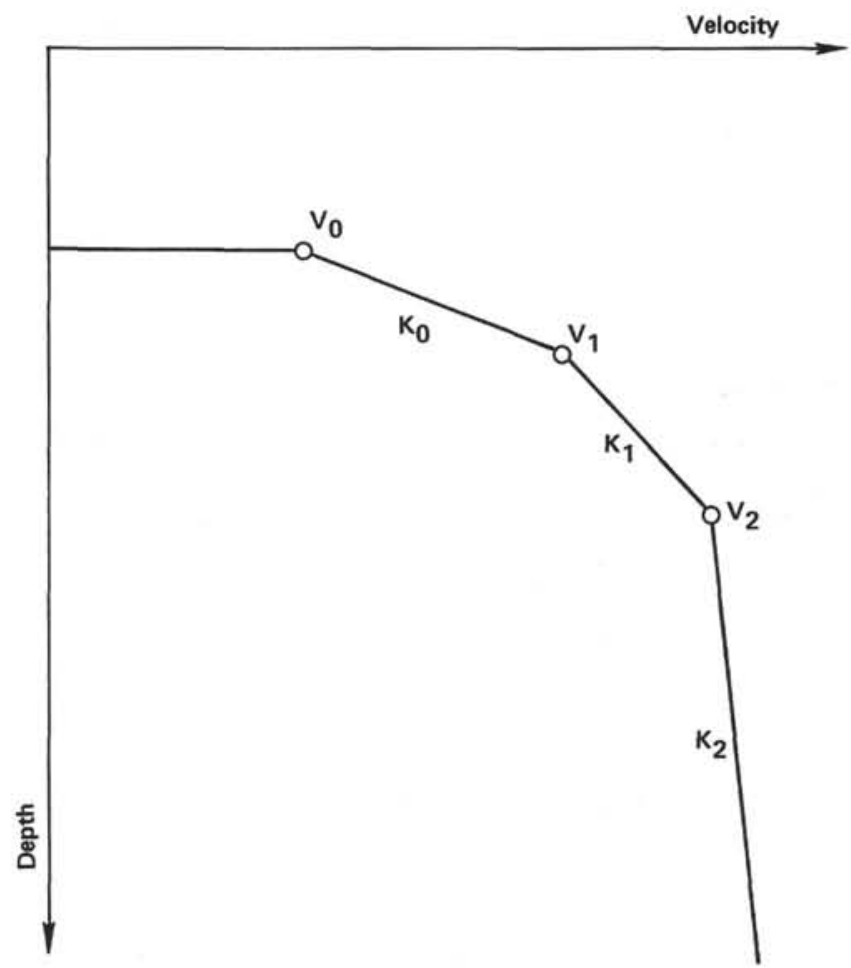

Figure 4. Schematic diagram showing the parameters used in the modeling procedures for basement structure (Tables 3 and 4).

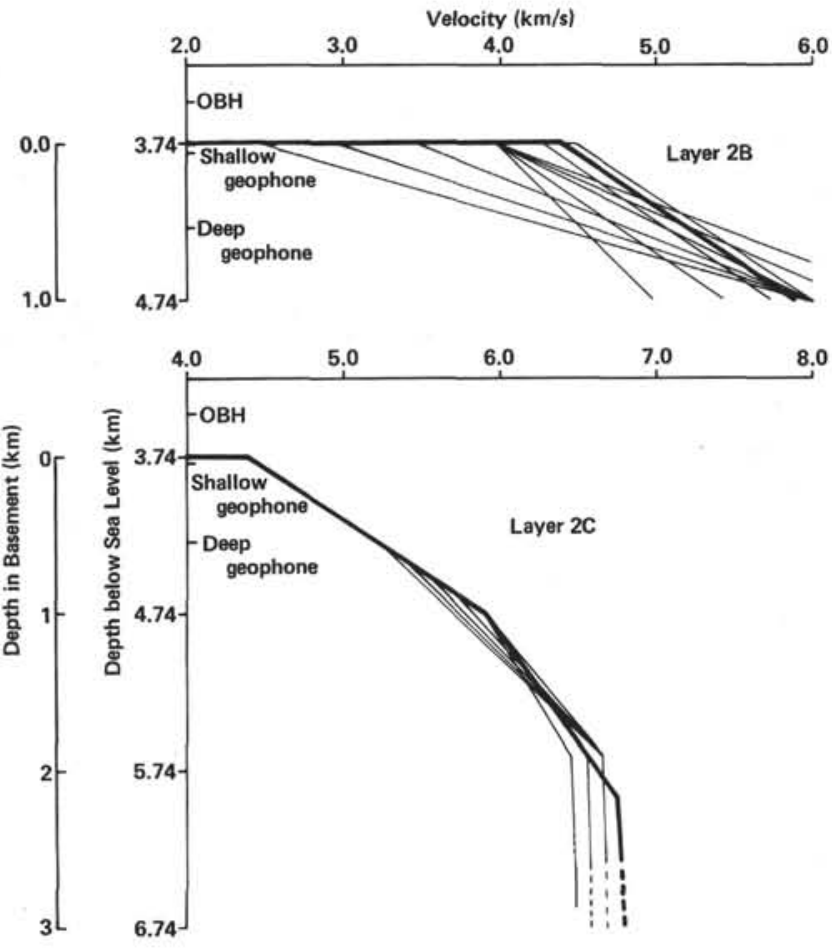

Figure 5. Velocity-depth models used in the modeling procedure for Layer $2 \mathrm{~B}$ and Layer $2 \mathrm{C}$. The heavy line indicates the best solution in each case.

Table 3. Velocity analysis for Layer 2B.

\begin{tabular}{|c|c|c|c|c|c|c|c|}
\hline & & \multicolumn{2}{|c|}{$\begin{array}{c}\text { OBH } 8 \\
(3.7-5.0 \mathrm{~km})\end{array}$} & \multicolumn{2}{|c|}{$\begin{array}{l}\text { Shallow } \\
\text { Geophone } \\
(0.7-4.0 \mathrm{~km})\end{array}$} & \multicolumn{2}{|c|}{$\begin{array}{c}\text { Deep } \\
\text { Geophone } \\
(0.7-4.0 \mathrm{~km})\end{array}$} \\
\hline & & $\begin{array}{l}\text { Velocity } \\
(\mathrm{km} / \mathrm{s})\end{array}$ & $\begin{array}{c}\text { Intercept } \\
\text { Time } \\
\text { (s) }\end{array}$ & $\begin{array}{l}\text { Velocity } \\
(\mathrm{km} / \mathrm{s})\end{array}$ & $\begin{array}{l}\text { Intercept } \\
\text { Time } \\
\text { (s) }\end{array}$ & $\begin{array}{l}\text { Velocity } \\
(\mathrm{km} / \mathrm{s})\end{array}$ & $\begin{array}{l}\text { Intercept } \\
\text { Time } \\
\text { (s) }\end{array}$ \\
\hline Observed & & $5.11 \pm 0.18$ & $2.600 \pm 0.040$ & $4.59 \pm 0.09$ & $2.379 \pm 0.011$ & $5.38 \pm 0.22$ & $2.469 \pm 0.019$ \\
\hline \multicolumn{8}{|l|}{ Models } \\
\hline $\begin{array}{c}\mathrm{V}_{0} \\
(\mathrm{~km} / \mathrm{s})\end{array}$ & $\underset{\left(s^{-1}\right)}{K_{0}}$ & & & & & & \\
\hline 2.5 & 3.5 & $6.02 \pm 0.02$ & $2.940 \pm 0.003$ & $3.46 \pm 0.05$ & $2.285 \pm 0.010$ & $5.01 \pm 0.05$ & $2.506 \pm 0.005$ \\
\hline 3.0 & 3.0 & $5.82 \pm 0.05$ & $2.864 \pm 0.006$ & $3.74 \pm 0.04$ & $2.311 \pm 0.008$ & $5.13 \pm 0.05$ & $2.490 \pm 0.005$ \\
\hline 3.5 & 2.5 & $5.30 \pm 0.06$ & $2.739 \pm 0.009$ & $4.05 \pm 0.03$ & $2.334 \pm 0.005$ & $5.28 \pm 0.05$ & $2.479 \pm 0.002$ \\
\hline 4.0 & 1.0 & $4.26 \pm 0.01$ & $2.528 \pm 0.002$ & $4.20 \pm 0.02$ & $2.338 \pm 0.004$ & $5.01 \pm 0.06$ & $2.457 \pm 0.007$ \\
\hline 4.0 & 1.45 & $4.53 \pm 0.02$ & $2.576 \pm 0.004$ & $4.26 \pm 0.02$ & $2.344 \pm 0.003$ & $5.20 \pm 0.06$ & $2.463 \pm 0.006$ \\
\hline 4.0 & 2.0 & $5.07 \pm 0.04$ & $2.561 \pm 0.007$ & $4.38 \pm 0.02$ & $2.353 \pm 0.002$ & $5.47 \pm 0.05$ & $2.472 \pm 0.005$ \\
\hline 4.0 & 2.33 & $5.45 \pm 0.05$ & $2.694 \pm 0.007$ & $4.47 \pm 0.03$ & $2.360 \pm 0.003$ & $5.65 \pm 0.05$ & $2.477 \pm 0.004$ \\
\hline 4.0 & 2.67 & $5.77 \pm 0.04$ & $2.719 \pm 0.006$ & $4.56 \pm 0.03$ & $2.368 \pm 0.004$ & $5.84 \pm 0.04$ & $2.483 \pm 0.003$ \\
\hline 4.3 & 1.5 & $4.87 \pm 0.02$ & $2.595 \pm 0.004$ & $4.55 \pm 0.02$ & $2.361 \pm 0.002$ & $5.51 \pm 0.06$ & $2.467 \pm 0.005$ \\
\hline 4.4 & 1.5 & $4.97 \pm 0.02$ & $2.598 \pm 0.004$ & $4.65 \pm 0.02$ & $2.366 \pm 0.002$ & $5.60 \pm 0.06$ & $2.468 \pm 0.005$ \\
\hline 4.5 & 1.5 & $5.08 \pm 0.02$ & $2.602 \pm 0.004$ & $4.74 \pm 0.02$ & $2.371 \pm 0.002$ & $5.70 \pm 0.06$ & $2.468 \pm 0.005$ \\
\hline
\end{tabular}


Table 4. Velocity analysis for Layer $2 \mathrm{C}$.

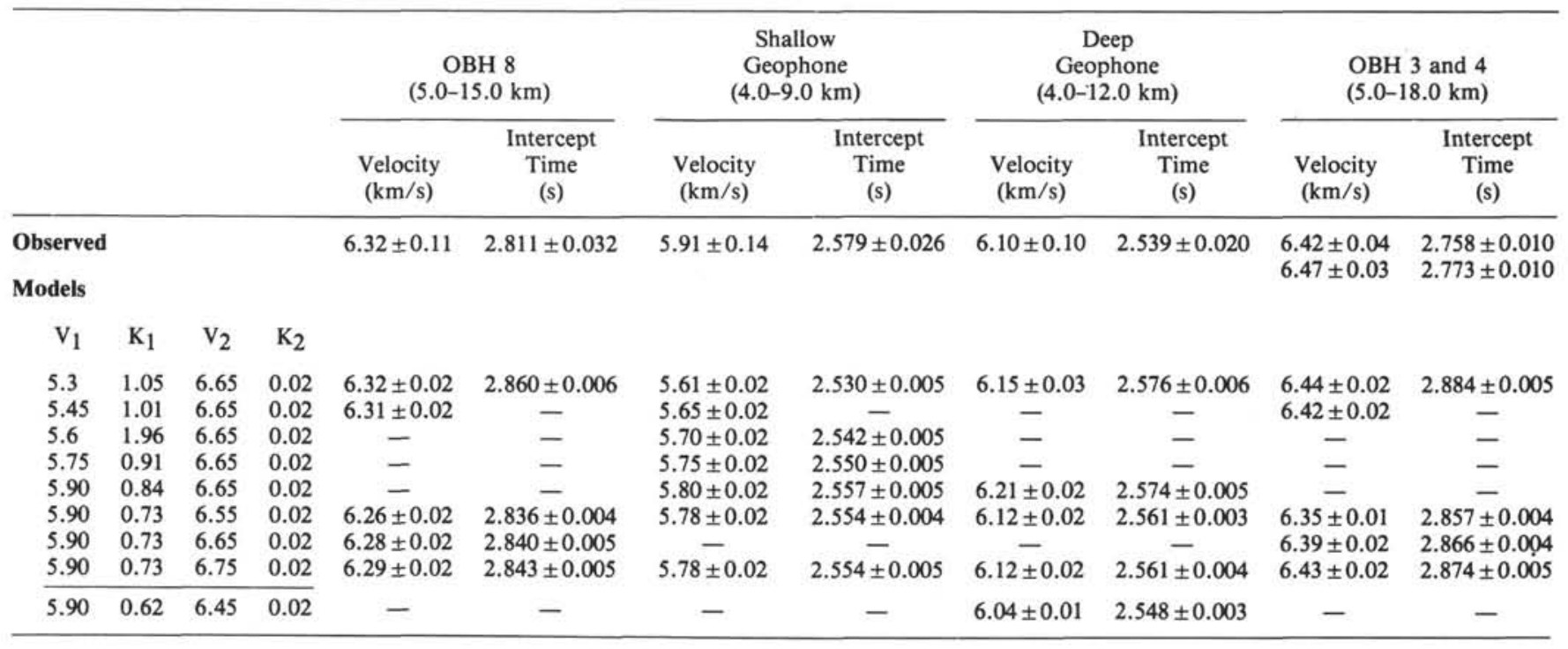
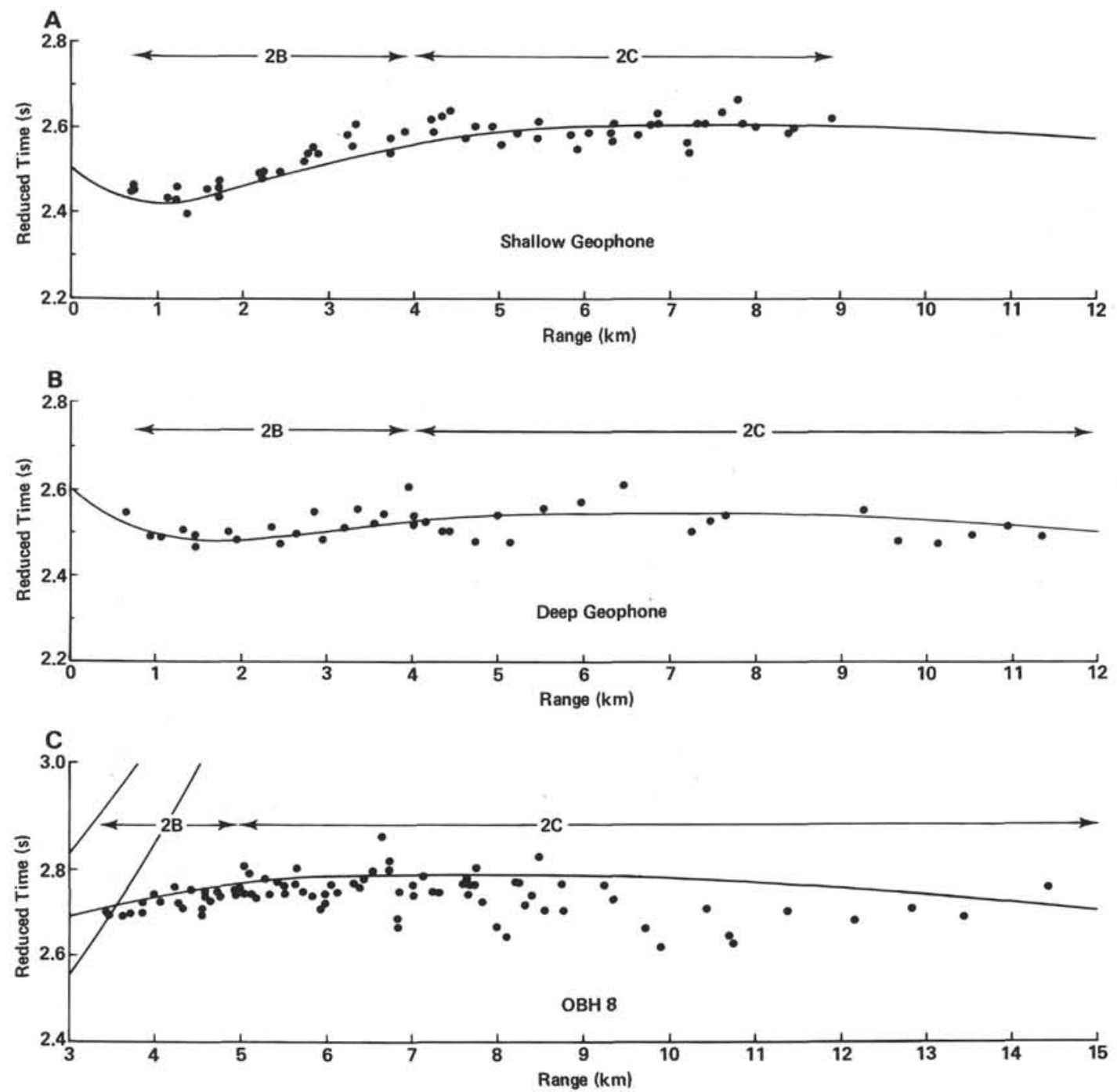

Figure 6. Travel-time curves for the best model in Figure 5 compared to the observed data. The reduction velocity is $6.0 \mathrm{~km} / \mathrm{s}$. A. Shallow geophone. B. Deep geophone. C. OBH 8. 